\title{
Kemampuan Pengguna dan Attitude Toward Change Memoderasi Pengaruh Perceived Usefulness pada Kinerja Sistem Informasi Akuntansi
}

\author{
I Kadek Dwi Handika Putra1 \\ Fakultas Ekonomi dan Bisnis \\ Universitas Udayana, Indonesia
}

\author{
Anak Agung Ngurah Bagus Dwirandra ${ }^{2}$ \\ Fakultas Ekonomi dan Bisnis \\ Universitas Udayana, Indonesia
}

Surel : dwihandikaputra15@gmail.com

\section{ABSTRAK}

Tujuan penelitian ini adalah pengaruh perceived usefulness terhadap kinerja sistem informasi akuntansi dengan kemampuan pengguna dan attitude toward change sebagai variabel moderasi. Penelitian ini menggunakan instrumen berupa kuesioner yang diberikan kepada 106 karyawan Lembaga Perkreditan Desa (LPD) Kecamatan Sukawati. Teknik analisis yang digunakan dalam penelitian ini adalah analisis regresi moderasi. Hasil pengujian menunjukkan bahwa perceived usefulness berpengaruh positif terhadap kinerja sistem informasi akuntansi, kemampuan pengguna berpengaruh positif terhadap kinerja sistem informasi akuntansi, kemampuan pengguna memperkuat pengaruh perceived usefulness pada kinerja sistem informasi akuntansi, atitude toward change berpengaruh positif terhadap kinerja sistem informasi akuntansi, dan variabel kemampuan pengguna tidak memoderasi pengaruh perceived usefulness pada kinerja sistem informasi akuntansi.

Kata Kunci: Perceived Usefulness; Kinerja Sistem Informasi Akuntansi; Kemampuan Pengguna; Attitude Toward Change.

\section{User Ability and Attitude Toward Change Moderate the Effect of Perceived Usefulness on Accounting Information System Performance}

\begin{abstract}
The goal of this study is to examine the impact of perceived usefulness on the performance of accounting information systems, with user ability and attitude toward change serving as moderating variables. The instrument used in this study was a questionnaire distributed to 106 employees of the Village Credit Institution (LPD) Sukawati District. In this study, moderated regression analysis was used as an analytical technique. The test results show that perceived usefulness has a positive effect on the performance of accounting information systems, that user ability has a positive effect on the performance of accounting information systems, and that perceived usefulness has a negative effect on the performance of accounting information systems. The attitude toward change has a positive effect on the performance of accounting information systems, and the ability variable users do not moderate the effect of perceived usefulness on the performance of accounting information systems.
\end{abstract}

Keywords: $\quad$ Perceived Usefulness; Accounting Information System Performance; User Capabilities; Attitude Toward Change.

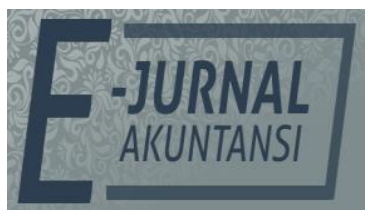

e-ISSN 2302-8556

Vol. 31 No. 9

Denpasar, September 2021 Hal. 2401-2414

DOI:

10.24843/EJA.2021.v31.i09.p20

PENGUTIPAN:

Putra, I.K.D.H., \& Dwirandra, A.A.N.B. (2021). Kemampuan Pengguna dan Attitude

Toward Change Memoderasi Pengaruh Perceived Usefulness pada Kinerja Sistem

Informasi Akuntansi. E-Jurnal Akuntansi, 31(9), 2401-2414

RIWAYAT ARTIKEL: Artikel Masuk: 17 Juli 2021 Artikel Diterima: 9 September 2021

Artikel dapat diakses : https://ojs.unud.ac.id/index.php/Akuntansi/index 


\section{PENDAHULUAN}

Perkembangan teknologi informasi sangat pesat, dan peningkatan penggunaan teknologi komputer merupakan pengaruh dari perkembangan teknologi informasi. Sebelum kemajuan teknologi informasi, sebagian besar penggunaan sistem informasi dan pribadi perusahaan dilakukan secara manual. Dengan berkembangnya teknologi informasi, banyak perusahaan beralih ke sistem informasi berbasis komputer karena akan memudahkan dan mempercepat pengelolaan dan pemrosesan input informasi. Xu \& Lu (2003) mengemukakan bahwa dalam perkembangan teknologi informasi saat ini, kualitas informasi sangat menentukan keberhasilan sistem informasi akuntansi.

Sistem informasi merupakan landasan operasional bisnis saat ini, karena organisasi membutuhkan sistem informasi untuk mempertahankan daya saingnya. Laudon \& Laudon (2008) mendefinisikan sistem informasi teknis dapat didefinisikan sebagai seperangkat komponen yang saling terkait untuk mengumpulkan, memproses, menyimpan, dan mendistribusikan informasi yang berguna sebagai alat pengambilan keputusan dan pemantauan organisasi. Perusahaan atau organisasi dapat menggunakan fasilitas teknologi informasi untuk meningkatkan kinerja (Alannita \& Suaryana, 2014). Peningkatan kinerja perusahaan dan bisnis melalui pemanfaatan teknologi memerlukan suatu sistem yang dapat menangkap, membuat, dan mengelola informasi secara internal dan eksternal. Informasi yang dihasilkan merupakan keluaran baru dari sistem informasi. Fungsi utama dari sistem informasi akuntansi adalah menghasilkan informasi berdasarkan data yang merupakan hasil transaksi keuangan (Tokic et al., 2011). Sistem informasi akuntansi memiliki peran yang sangat potensial dalam mengembangkan dan menyediakan informasi sebagai pengendalian manajemen dan penunjang pengambilan keputusan.

Asal usul sejarah kegiatan perbankan dapat dipelajari dari pengenalan layanan penukaran mata uang. Dalam sejarah perbankan, pengertian bank disebut tabel perubahan mata uang. Secara historis, pedagang di berbagai kerajaan menukar uang untuk transaksi, dan uang dipertukarkan antara satu jenis pekerjaan dengan pekerjaan lainnya. Kegiatan penukaran mata uang sekarang dikenal dengan istilah pedagang valuta asing (money change). Dalam perkembangan selanjutnya, industri perbankan kembali berkembang menjadi currency custody atau biasa disebut deposito. Selain itu, bisnis perbankan meningkat seiring dengan kegiatan peminjaman uang. Bank akan meminjamkan uang yang disimpan oleh masyarakat kepada orang yang membutuhkan. Layanan perbankan lainnya mengikuti dan beradaptasi dengan beragam kebutuhan ekonomi zaman dan masyarakat (Dendawijaya, 2009).

Dalam perkembangannya, lembaga keuangan dapat dibedakan menjadi dua bentuk yaitu bank dan non bank. Perbedaan kedua bentuk bank dan lembaga non bank ini terletak pada penghimpunan dananya. Dalam hal penghimpunan dana diatur bahwa bank dapat secara langsung maupun tidak langsung menghimpun dana dari masyarakat, sedangkan lembaga keuangan bukan bank hanya dapat menghimpun dana secara tidak langsung dari masyarakat (Dendawijaya, 2009). 
Lembaga keuangan, termasuk bank dan lembaga keuangan bukan bank, memegang peranan yang sangat penting dalam kegiatan perekonomian. Peran lembaga keuangan ini adalah sebagai alat yang secara efektif dapat menghimpun dan menyalurkan dana kepada masyarakat untuk menjaga kelangsungan ekonomi masyarakat. Salah satu bentuk lembaga keuangan non bank adalah Lembaga Perkreditan Rakyat (LPD). Lembaga Perkreditan Rakyat (LPD) adalah lembaga keuangan milik Desa Pakraman untuk mengelola dana masyarakat setempat. LPD bertujuan untuk mendorong perkembangan ekonomi masyarakat dan diharapkan dapat membantu masyarakat dengan memberikan kemudahan dalam memberikan pinjaman dalam bentuk kredit atau memberikan simpanan dalam bentuk simpanan (Suartana, 2009).

Lembaga keuangan sudah mulai menggunakan sistem informasi akuntansi berbasis komputer, salah satunya adalah Badan Perkreditan Desa, badan usaha keuangan milik Desa Pakraman yang melakukan kegiatan usaha di lingkungan pedesaan dan melayani masyarakat pedesaan setempat. Suartana (2009) menilai kinerja LPD membutuhkan laporan keuangan yang baik dan lengkap, sehingga diperlukan juga sistem informasi akuntansi yang didukung oleh teknologi informasi komputer. Artinya jika ingin meningkatkan kinerja LPD maka harus memiliki kinerja sistem informasi yang baik sebagai penunjangnya. Agar sebuah LPD dapat menghasilkan kinerja yang baik, sebaiknya sistem yang digunakan di dukung oleh sistem informasi yang terkomputerisasi.

Sistem Informasi Akuntansi (SIA) berfungsi mengumpulkan dan memproses data transaksi, serta mengomunikasikan informasi-informasi keuangan yang sudah terproses kepada pihak-pihak yang membutuhkan. Dalam proses pengadopsian atau penerapan teknologi informasi, terdapat faktor-faktor yang mendukung untuk penerapan teknologi informasi agar dapat diterima oleh masyarakat salah satunya yaitu persepsi kemanfaatan (Ariyanto et al., 2014) dan (Davis, 1989).

Persepsi kemanfaatan juga akan mempengaruhi proses implementasi sistem informasi akuntansi. Masyarakat memiliki anggapan besar bahwa melalui penggunaan LPD dan penerapan sistem informasi akuntansi dalam transaksi LPD, masyarakat akan memperoleh manfaat yang tidak dirasakan apabila bertansaksi pada lembaga nonbank lainnya (Julianto \& Yasa, 2019; Suardikha, 2013; Yogiswara \& Suardikha, 2018). Penerapan sistem informasi akuntansi di LPD akan mempengaruhi persepsi masyarakat, karena jika LPD adalah tempat mereka menyimpan uang dalam bentuk tabungan, deposito dan bentuk lainnya maka mengindikasikan bahwa LPD dalam keadaan yang sehat. Sehingga, masyarakat akan merasa aman dan nyaman untuk menyimpan uang (Suartana, 2009).

Dewi \& Warmika (2017) dan Jogiyanto (2010) mendefinisikan persepsi kemanfaatan sebagai sejauh mana seseorang percaya bahwa menggunakan teknologi akan meningkatkan kinerjanya. Perceived usefullness didefinisikan sebagai sejauh mana seseorang percaya bahwa menggunakan sistem informasi tertentu akan meningkatkan kinerjanya. Menurut definisi ini, kita tahu bahwa persepsi kemanfaatan adalah keyakinan dalam proses pengambilan keputusan. Jika seseorang berpikir sistem itu berguna, maka dia akan menggunakannya. Sebaliknya, jika seseorang berpikir bahwa sistem informasi tidak terlalu berguna, maka dia tidak akan menggunakannya. Konsep ini juga menggambarkan manfaat 
sistem bagi pengguna, termasuk produktivitas (productivity), kinerja atau efektivitas pekerjaan (task performance atau efektivitas), kepentingan pekerjaan (importance of the task), dan kegunaan keseluruhan (overall usefulness) (Davis, 1989) dan (Santoso, 2010).

Definisi kinerja Gustiyan (2014) adalah mengevaluasi pekerjaan seseorang sesuai dengan tujuan yang telah ditentukan. Oleh karena itu, kesimpulan dapat ditarik dari pemahaman para ahli tersebut di atas tentang kinerja. Kinerja merupakan suatu kondisi yang harus dikomunikasikan dan dipahami oleh pihakpihak tertentu agar dapat mengetahui sejauh mana hasil yang telah dicapai perusahaan sehingga pihak yang membutuhkan informasi merasa puas dengan keputusan yang diambil. Selain itu, sistem merupakan rangkaian dari dua atau lebih komponen yang mempunyai hubungan dan interaksi dalam mencapai tujuan tertentu. Tujuan dari sistem adalah untuk menghubungkan berbagai bagian dari sistem. Pengertian selanjutnya adalah informasi. Gustiyan (2014) dan Susanto (2014) menjelaskan bahwa informasi merupakan hasil pengolahan data, memberikan makna dan manfaat. Informasi adalah data yang diolah menjadi bentuk yang lebih berguna bagi penerimanya. Selanjutnya adalah pengertian sistem informasi akuntansi. Septianingrum (2014) mendefinisikan sistem informasi akuntansi adalah susunan berbagai bentuk catatan, peralatan (termasuk komputer dan peralatan) serta alat komunikasi, eksekutif, dan laporan yang terkoordinasi secara erat, yang dirancang untuk mengubah data keuangan menjadi informasi yang dibutuhkan manajemen. Oleh karena itu, dari beberapa definisi yang telah dijelaskan oleh para ahli sehingga dapat ditarik kesimpulan tentang pengertian sistem informasi akuntansi. Sistem informasi akuntansi adalah suatu sistem yang dirancang untuk mengolah data dan informasi.

Penelitian sebelumnya telah menunjukkan bahwa hasilnya beragam, tidak konsisten atau kontroversial, yang diyakini karena faktor lain yang mempengaruhi hubungan antara variabel independen dan variabel dependen. Govindarajan (1986) mengemukakan bahwa menurut faktor-faktor tertentu yang disebut faktor kontingensi, tidak mungkin ada suatu hasil penelitian yang terpadu. Murray (1990) berpendapat bahwa untuk dapat menengahi hasil penelitian yang saling bertentangan, diperlukan metode kontingensi untuk mengidentifikasi variabel lain yang berperan sebagai regulator atau mediator dalam model penelitian.

Menurut sumber dari Badan Pemberdayaan Badan Perkreditan Desa, masih terdapat beberapa LPD di Kabupaten Sukawati yang belum mengoptimalkan penggunaan sistem informasi akuntansi secara lengkap dan terkomputerisasi, sehingga LPD tersebut belum mampu bersaing dengan kinerja sistem informasi tersebut. Efisiensi akuntansi LPD yang dihasilkan oleh input, output dan informasi rendah. Dari sisi pengembangan aset LPD, pemanfaatan LPD SIA yang berintegritas dan berkemampuan adalah karena pemanfaatan teknologi informasi yang optimal sehingga memungkinkan LPD untuk bersaing yang dapat dikatakan cukup sehat (Suartana, 2009). 
Lembaga Perkreditan Desa semakin banyak diminati oleh masyarakat karena selain pelayanan yang ramah cepat dan mudah, sekarang LPD juga telah mampu memberikan fasilitas serta penawaran penawaran yang menarik. Di Bali terdapat 1.433 LPD namun sebanyak 158 LPD dinyatakan bangkrut karena sudah tidak beroperasi lagi. Dari data tersebut perlu adanya evaluasi apakah yang menyebabkan LPD tidak dapat bersaing di lapangan dan akhirnya harus ditutup karena bangkrut. Lembaga perkreditan Desa di Sukawati mengalami beberapa kendala akibat adanya persepsi kegunaan yang mempengaruhi kinerja sistem informasi akuntansi, oleh karena itu perlu adanya kemampuan pengguna dan perubahan sikap yang siap dalam menanggapi perubahan tersebut.

Kegunaan yang dirasakan didefinisikan sebagai sejauh mana seseorang percaya bahwa menggunakan sistem tertentu dapat meningkatkan kinerja (Tan et al., 2012). Persepsi kemudahan penggunaan didefinisikan oleh Tan et al. (2012) Sebagai suatu level kemudahan. Beberapa orang berpikir bahwa menggunakan sistem tidak memerlukan usaha apa pun (no effort). Oleh karena itu, model TAM dapat menjelaskan bahwa persepsi pengguna akan menentukan sikapnya terhadap kegunaan penggunaan sistem informasi. Model ini lebih jelas menunjukkan bahwa penerimaan penggunaan sistem informasi dipengaruhi oleh persepsi kegunaan, sehingga penggunaan sistem informasi yang baik dapat membuat kinerja sistem informasi akuntansi itu sendiri lebih bermanfaat (Buana \& Wirawati, 2018), (Pavlou, 2001), dan (Perkasa, 2016).

$\mathrm{H}_{1}$ : Persepsi kegunaan berpengaruh positif pada kinerja sistem informasi akuntansi.

Pelatihan dan pendidikan pengguna sistem informasi akuntansi tentunya membantu pengguna sistem untuk berpartisipasi dalam pengoperasian sistem informasi akuntansi. Robbins \& Judge (2008) memahami bahwa kemampuan pengguna adalah kemampuan individu untuk menyelesaikan berbagai tugas di tempat kerja. Robbins \& Judge (2008) menyatakan kemampuan pemakai dapat dilihat dari pengetahuan, kemampuan dan keterampilan. Pengukuran kapabilitas pengguna sistem informasi dalam penelitian ini didasarkan pada dimensi pengetahuan, kapabilitas, dan pengetahuan profesional pengguna sistem informasi dengan indikator: memiliki pengetahuan SIA, memahami tugas dan tugas, mampu menjalankan sistem, mampu melakukan tugas dan tugas, serta memiliki keahlian (professional ability) (Dharmawan \& Ardianto, 2017), (Fatmawati et al., 2019), (Jayanti et al., 2017), dan (Septianingrum, 2014).

$\mathrm{H}_{2}$ : Kemampuan pengguna meningkatkan kinerja sistem informasi akuntansi.

Penelitian yang dilakukan Putri \& Dharmadiaksa (2015) dan Widyantari \& Suardikha (2016) menunjukkan bahwa kapabilitas pengguna berpengaruh positif dan signifikan terhadap kinerja AIS. Berbeda dengan hasil Prabowo et al. (2014), hasil ini menunjukkan bahwa kemampuan pengguna tidak berpengaruh signifikan terhadap kinerja AIS. Model penerimaan teknologi menunjukkan bahwa perilaku pengguna pada sistem informasi didasarkan pada dua keyakinan, yaitu kegunaan dan kemudahan penggunaan (Davis, 1985). Semakin mudah dan bermanfaat pengguna dalam menggunakan sistem informasi tersebut, maka semakin baik pula ia memahami sistem yang dioperasikan oleh lembaga perkreditan desa, sehingga pengguna dapat mengoperasikan sistem informasi seperti yang diharapkan. 
$\mathrm{H}_{3}$ : Kemampuan Pengguna meningkatkan pengaruh perceived usefulness pada kinerja sistem informasi akutansi.

Sikap adalah kecenderungan untuk bereaksi positif atau negatif terhadap seseorang atau sesuatu (Colaizzi, 1973). Sikap terhadap perubahan organisasi (Khatoon \& Farooq, 2014) adalah sikap emosional karyawan untuk menilai dampak baik dan buruk dari perubahan. Mereka juga percaya bahwa perubahan adalah wilayah dari sikap positif yang kuat (keterbukaan, kemauan untuk berubah) ke sikap negatif (perlawanan, pesimisme). Berdasarkan pengertian di atas, sikap positif karyawan terhadap perubahan organisasi memegang peranan penting dalam mencapai tujuan organisasi. Cummings \& Worley (2008) memiliki dua jenis perubahan, yaitu perubahan yang baru saja terjadi dan perubahan yang direncanakan. Perubahan rencana adalah perubahan yang disengaja dan berorientasi pada tujuan. Perubahan terencana memiliki dua tujuan, yaitu: (1) Perubahan yang dilakukan organisasi merupakan upaya perbaikan untuk beradaptasi dengan perubahan lingkungan; (2) Perubahan yang ditujukan untuk mengubah sikap karyawan. Dengan perubahan sikap ini, saya berharap dapat memprediksi dan memahami dengan benar sehingga kinerja sistem informasi juga dapat beroperasi secara normal.

$\mathrm{H}_{4}$ : Atitude toward change berpengaruh positif pada kinerja sistem informasi akutansi.

Pengguna sistem informasi perusahaan adalah sumber daya informasi yang penting dan dapat memberikan kontribusi nyata untuk mencapai tujuan strategis dan memperoleh keunggulan kompetitif. Ini terutama benar ketika pengguna dapat secara aktif berpartisipasi dalam pengembangan sistem dan mempraktikkan komputasi pengguna akhir. Susanto (2014) menjelaskan pentingnya partisipasi pengguna dalam pengembangan sistem informasi. Pengguna adalah orang di dalam perusahaan. Analis sistem adalah orang di luar perusahaan. Sistem informasi dikembangkan bukan untuk pembuat sistem tapi untuk pemakai agar sistem dapat diterapkan, sistem tersebut harus bisa menyerap kebutuhan pemakai dan yang tahu kebutuhan pemakai adalah pemakai sendiri, sehingga keterlibatan pengguna dalam pengembangan sistem akan meningkatkan tingkat keberhasilan walaupun memberikan jaminan berhasil". Susanto (2014) menyatakan bahwa efektifitas dari setiap aplikasi komputer dipengaruhi oleh keterlibatan user dalam proses dalam perancangan dan pengembangan SIA dan oleh kualitas dukungan yang diberikan $u$ ser.

Pengaruh partisipasi pengguna yang bisa disebut karyawan atau personil sangat menentukan keberhasilan penerapan sistem informasi akuntansi dalam sebuah perusahaan (Puspitawati \& Anggadini, 2011). Baik buruknya kinerja dari sebuah sistem informasi akuntansi dapat dilihat melalui kepuasan pemakai sistem informasi akuntansi dan pemakaian dari sistem informasi akuntansi itu sendiri (Sudibyo \& Kuswanto, 2011). Tingginya kepuasan pemakai diperoleh dari pemakai yang mempunyai partisipasi dalam pengembangan sistem. Keterlibatan pengguna yang semakin sering akan meningkatkan kinerja sistem informasi akuntansi, dikarenakan adanya hubungan yang positif antara keterlibatan 
pengguna dalam proses pengembangan sistem informasi dalam kinerja sistem informasi akuntansi (Almilia \& Briliantien, 2007). Dilihat dari uraian tersebut, dapat disimpulkan hipotesis terakhir yang diuji pada penelitian ini yaitu:

$\mathrm{H}_{5}$ : Atitude toward change meningkatkan pengaruh perceived usefulness pada kinerja sistem informasi akutansi.

\section{METODE PENELITIAN}

Pendekatan penelitian yang digunakan dalam penelitian ini adalah penelitian kuantitatif. Populasi dalam penelitian ini adalah seluruh karyawan LPD di Kecamatan Sukawati. Berdasarkan data yang didapat, karyawan pada LPD di Kecamatan Sukawati adalah 106 orang kurang dari 120, maka diambil seluruhnya, sehingga penelitian ini merupakan penelitian populasi. Maka metode pengambilan sampel adalah dengan metode sampling jenuh. Sehingga, responden dalam penelitian ini adalah karyawan dan ketua LPD yang bekerja dan telah terlibat langsung dalam penggunaan SIA selama lebih dari satu tahun. Penelitian ini menggunakan instrumen berupa kuesioner, yang kemudian disebarkan ke 22 LPD di Kecamatan Sukawati.

Perceived usefulness di ukur dengan menggunakan instrumen pernyataan yang di gunakan oleh Davis (1989) diantarannya pekerjaan menjadi lebih cepat, mengembangkan kinerja pekerja, menambah produktivitas, mempertinggi efektivitas, pekerjaan menjadi lebih mudah dan berguna bagi pekerja. Attitude toward change menggunakan instrumen pernyataan dari Hamid et al. (2017) dengan indicator perubahaan kemampuan untuk mengontrol, penolakan ide baru, frustrasi akan perubahan, kebergunaan perubahan, keinginan untuk melakukan perubahan dan pengusulan terhadap perubahan.

Menurut Luthan kinerja tidak hanya dipengaruhi oleh sejumlah usaha yang dilakukan seseorang tetapi dipengaruhi pula oleh kemampuannya. Robbins mengatakan bahwa kinerja seseorang sangat dipengaruhi oleh faktor kemampuan atau ability (A), motivasi atau motivation (M), dan kesempatan atau opportunity $(\mathrm{O})$; yaitu performance $=\mathrm{f}(\mathrm{AxMxO})$, artinya kinerja merupakan fungsi dari kemampuan, motivasi, dan kesempatan. Indikator yang digunakan dalam penelitian ini adalah pengetahuan (knowledge) tentang sistem informasi, kemampuan (abilities), keahlian (skills) dalam penggunaan teknologi, niat untuk menggunakan dan sikap. Indikator kinerja sistem informasi akuntansi dalam penelitian ini dikembangkan dari (Ronaldi, 2012), yang mencakup konsumsi berkualitas, menjadikan pekerjaan lebih mudah, bermanfaat, meningkatkan produktivitas, mempertinggi efektivitas dan mengembangkan kinerja perusahaan.

Teknik analisis data dalam penelitian ini dilakukan dengan menggunakan Moderated Regression Analysis (MRA) dengan menggunakan program SPSS 39 (Statistical Product and Service Solution). Model persamaan struktural dalam penelitian ini dinyatakan sebagai berikut.

$Y=\alpha+\beta_{1} X+\beta_{2} M_{1}+\beta_{3} M_{2}+\beta_{4} X \cdot M_{1}+\beta_{5} X . M_{2}+\varepsilon$

Keterangan:

$\mathrm{Y}=$ Kinerja Sistem Informasi Akuntansi

$\mathrm{X}_{1} \quad=$ Perceived Usefulness

$\mathrm{M}_{1} \quad=$ Attitude Toward Change 
$\mathrm{M}_{2} \quad=$ Kemampuan Pengguna

$\mathrm{X}_{1} \mathrm{Z}_{1} \quad=$ Interaksi antara Perceived Usefulness dan Attitude Toward Change

$\mathrm{X}_{1} \mathrm{Z}_{2}=$ Interaksi antara Perceived Usefulness dan Kemampuan Pengguna

$\alpha \quad=$ Konstanta

$\beta_{1-} \beta_{5}=$ Koefisien regresi (nilai peningkatan atau pun penurunan)

$\varepsilon \quad=$ Error Term, yaitu tingkat kesalahan penduga dalam penelitian

\section{HASIL DAN PEMBAHASAN}

Karakteristik responden merupakan profil dari 106 responden yang berpartisipasi dalam penelitian ini meliputi jenis kelamin, umur, tingkat pendidikan, lama bekerja. Rincian karakteristik responden dapat dilihat pada Tabel 1.

Tabel 1. Karakteristik Responden

\begin{tabular}{|c|c|c|c|c|}
\hline No. & Variabel & Klasifikasi & Jumlah & Presentase (\%) \\
\hline \multirow[t]{3}{*}{1.} & Jenis Kelamin & Perempuan & 40 & 37,7 \\
\hline & & Laki-laki & 66 & 62,3 \\
\hline & & Total & 106 & 100 \\
\hline \multirow[t]{5}{*}{2.} & Umur & $20-30$ & 39 & 36,8 \\
\hline & & $31-40$ & 25 & 23,6 \\
\hline & & $41-50$ & 20 & 18,9 \\
\hline & & $>50$ & 22 & 20,7 \\
\hline & & Total & 106 & 100 \\
\hline \multirow[t]{5}{*}{3.} & Tingkat Pendidikan & SMA atau SMK & 0 & 0 \\
\hline & & Diploma & 59 & 55,7 \\
\hline & & S1 & 47 & 44,3 \\
\hline & & Lainnya & 0 & 0 \\
\hline & & Total & 106 & 100 \\
\hline \multirow[t]{6}{*}{4.} & Masa Kerja & $>3$ & 4 & 3,8 \\
\hline & & $3-10$ & 23 & 21,7 \\
\hline & & $11-20$ & 30 & 28,3 \\
\hline & & $21-30$ & 36 & 34 \\
\hline & & $>30$ & 13 & 12,2 \\
\hline & & Total & 106 & 100 \\
\hline
\end{tabular}

Sumber: Data Penelitian, 2021

Data karakteristik responden pada Tabel 1, menunjukkan bahwa responden laki-laki mendominasi dengan jumlah 66 orang (62,3 persen) dan responden perempuan berjumlah 40 orang (37,7 persen). Apabila dilihat dari kategori umur, responden berumur 20-30 tahun mendominasi dengan jumlah 39 orang (36,8 persen), umur 31-40 tahun berjumlah 25 orang (23,6 persen), umur $41-50$ tahun berjumlah 20 (18,9 persen), umur $>50$ tahun berjumlah 22 orang (20,7 persen). Berdasarkan data tersebut dapat dikatakan kredibel karena usia karyawan tergolong usia yang milenial. Umur dari karyawan tersebut dianggap lebih mampu dalam menerima perubahan yang terjadi seperti di era global saat ini. Sementara itu, dari kategori pendidikan, Diploma berjumlah 59 orang (55,7 persen), pendidikan S1 berjumlah 47 orang (44,3 persen). Pendidikan dari karyawan LPD rata rata lulusan Diploma dan S1. Dengan begitu hasil kuesioner tersebut juga dapat dikatakan kredibel, karena data kuesioner diisi oleh karyawan 
yang sudah menyeselasikan pendidikan tinggi. Masa kerja dapat digunakan untuk mengetahui pengalaman responden dalam bekerja selama kurang dari 3 tahun berjumlah 4 orang (3,8 persen), bekerja 3-10 tahun berjumlah 23 orang (21,7 persen), bekerja 11-20 tahun berjumlah 30 orang (28,3 persen), bekerja 21-30 tahun berjumlah 36 orang (34 persen), bekerja >30 tahun berjumlah 13 orang (12,2 persen). Dengan masa kerja yang lumayan lama, maka akan menambah hasil data yang lebih efektif, sebab data tersebut dibuat sesuai dengan pengalaman kerja karyawan yang telah banyak melewati evaluasi selama kerja.

Pengujian validitas dilakukan pada instrumen penelitian dengan metode pearson correlation dan diperoleh bahwa seluruh indikator pada instrumen penelitian ini adalah valid dan dapat digunakan karena memiliki nilai Pearson Correlation lebih dari 0,3. Pengujian reliabilitas instrumen menggunakan cronbach alpha dengan signifikansi yang digunakan lebih besar dari 0,70 dan diperoleh hasil bahwa keempat indikator yang menggambarkan variabel penelitian memiliki nilai Cronbach's alpha lebih besar dari 0,7 sehingga pernyataan dalam kuesioner reliabel.

Teknik analisis regresi moderasi digunakan karena pada penelitian ini dirancang untuk meneliti variabel independen yang berpengaruh terhadap variabel dependen dengan menggunakan interaksi variabel moderasi. Hasil pengujian ditunjukkan pada Tabel 2.

Tabel 2. Hasil Analisis Regresi Moderasi

\begin{tabular}{llcrrrr}
\hline \multicolumn{1}{c}{ Model } & $\begin{array}{c}\text { Exp. } \\
\text { Correlation }\end{array}$ & Coefficient & Std. Error & t-ratio & -value \\
\hline 1 (Constant) & - & $-8,723$ & 10,106 & $-0,863$ & 0,390 \\
Perceived Usefulness $(\mathrm{X})$ & + & 0,826 & 0,409 & 2,020 & $0,046^{* *}$ \\
Kemampuan Pengguna & + & 0,180 & 0,810 & 0,222 & $0,025^{* *}$ \\
& $\left(\mathrm{M}_{1}\right.$ & & & & & \\
Atitude Toward Change & $\left(\mathrm{M}_{2)}\right)$ & + & 0,914 & 0,594 & 1,538 & $0,014^{* *}$ \\
$\mathrm{XM}_{1}$ & + & 0,001 & 0,031 & 0,038 & $0,030^{* *}$ \\
$\mathrm{XM}_{2}$ & + & $-0,020$ & 0,023 & $-0,907$ & 0,377 \\
$\mathrm{~F}$ & 67,639 & & & & \\
$\mathrm{R}^{2}$ & 0,772 & & & & \\
Adj. $\mathrm{R}^{2}$ & 0,760 & & & &
\end{tabular}

Sumber: Data Penelitian, 2021

Berdasarkan Tabel 2, hasil penelitian diketahui bahwa variabel Perceived Usefulness berpengaruh positif terhadap kinerja sistem informasi akuntansi. Hasil analisis menunjukkan bahwa nilai signifikansi uji $\mathrm{t}$ untuk variabel persepsi kegunaan sebesar 0,046 yaitu lebih kecil dari taraf nyata 0,05 . Hal ini menunjukkan bahwa persepsi kegunaan berpengaruh pada kinerja sistem informasi akuntansi. Koefisien regresi bernilai positif sebesar 0,826. Artinya persepsi kegunaan menunjukkan arah positif dengan kegunaan system informasi akuntansi. Hipotesis pertama $\left(\mathrm{H}_{1}\right)$ pada penelitian ini diterima.

Semakin baik persepsi kegunaan oleh pengguna sistem informasi akuntansi, maka hal ini menandakan bahwa semakin baik pula kinerja sistem informasi akuntansi tersebut. Sistem yang memiliki kecanggihan teknologi tentu membantu perusahaan untuk menghasilkan informasi yang lebih akurat serta cepat dalam membuat keputusan. Hasil penelitian ini didukung oleh penelitian sebelumnya yang dilakukan. Perbarini \& Juliarsa (2012) yang menyatakan bahwa ada hubungan yang positif antar partisipasi pemakai dengan kinerja sistem informasi 
akuntansi yang diukur dengan kepuasan pengguna. Kemanfaatan juga mempengaruhi kemudahan, tetapi tidak sebaliknya. Hasil penelitian ini mengkonfirmasi teori Technology Acceptance Model (TAM) yang menyatakan bahwa persepsi manfaat adalah faktor penentu dapat diterimanya sebuah SIA atau sebuah teknologi. Pengurus dan pegawai LPD yang beranggapan bahwa dengan menggunakan suatu sistem tertentu akan dapat membantu meningkatkan kinerja dan prestasi kerja terhadap individu tersebut.

Berdasarkan Tabel 2, hasil penelitian diketahui bahwa variabel kemampuan pengguna berpengaruh positif terhadap kinerja sistem informasi akuntansi. Hasil analisis menunjukkan bahwa nilai signifikansi uji $\mathrm{t}$ untuk variabel kemampuan pengguna sebesar 0,025 yaitu lebih kecil dari taraf nyata 0,05 . Hal ini menunjukkan bahwa kemampuan pengguna berpengaruh pada kinerja sistem informasi akuntansi. Koefisien regresi bernilai positif sebesar 0,180. Artinya kemampuan pengguna menunjukkan arah positif dengan kinerja sistem informasi akuntansi. Hipotesis kedua $\left(\mathrm{H}_{2}\right)$ pada penelitian ini diterima.

Semakin baik kemampuan pengguna, maka hal ini menandakan bahwa semakin baik pula kinerja sistem informasi akuntansi tersebut. Robbins dan Judge (2005:46) menyatakan pengertian kemampuan pengguna adalah suatu kapasitas individu untuk mengerjakan berbagai tugas dalam suatu pekerjaan. Kemampuan pengguna yaitu dapat dilihat dari "Knowledge, Ability, and Skills" (Robbins \& Judge, 2008). Kemampuan Pengguna Sistem informasi dalam penelitian ini diukur berdasarkan dimensi pengetahuan, kemampuan, dan keahlian pengguna sistem informasi dengan indikator: memiliki pengetahuan SIA, memahami tugas dan pekerjaan, mampu menjalankan sistem, mampu mengerjakan tugas dan pekerjaan, memiliki keahlian (kemampuan spesialis).

Berdasarkan Tabel 2, hasil penelitian diketahui bahwa variabel Perceived Usefulness dengan Kemampuan Pengguna (X.M $\mathrm{M}_{1}$ ) menunjukkan hipotesis ketiga dalam penelitian ini diterima, dikarenakan hasil penelitian ini telah sesuai berdasarkan hasil uji $\mathrm{t}$ dengan kriteria $\mathrm{H}_{3}$ diterima yaitu kemampuan pengguna terbukti mampu memoderasi (memperkuat) pengaruh Perceived Usefulness pada kinerja sistem informasi akuntansi.

Hipotesis ketiga $\left(\mathrm{H}_{3}\right)$ pada penelitian ini menyatakan bahwa kemampuan pengguna memoderasi pengaruh Perceived Usefulness pada kinerja sistem informasi akuntansi. Hasil analisis menunjukkan bahwa nilai signifikansi uji $t$ untuk variabel persepsi kegunaan dengan kemampuan pengguna (X.M1) sebesar 0,030 yaitu lebih kecil dari taraf nyata 0,05 . Hal ini menunjukkan bahwa persepsi kegunaan dengan kemampuan pengguna (X.M1) berpengaruh pada kinerja sistem informasi akuntansi. Koefisien regresi bernilai positif sebesar 0,001. Artinya kemampuan pengguna memoderasi pengaruh Perceived Usefulness pada kinerja sistem informasi akuntansi. Hipotesis ketiga $\left(\mathrm{H}_{3}\right)$ pada penelitian ini diterima.

Hasil penelitian ini mengkonfirmasi Teori TAM yang menyatakan bahwa perilaku pengguna terhadap sistem informasi didasarkan oleh dua keyakinan yaitu kebermanfaatan (usefulness) dan kemudahan (ease of use). Semakin mudah dan bermanfaat pengguna menggunakan sistem informasi, maka akan 
meningkatkan pemahaman pengguna dalam menjalankan sistem yang dioperasikan pada Lembaga Perkreditan Desa tersebut. sehingga para pengguna dapat mencapai hasil sesuai yang diharapkan.

Hasil penelitian ini mendukung penelitian sebelumnya yang dilakukan oleh Putri \& Dharmadiaksa (2015) yang menyatakan bahwa kemampuan pengguna atau pemakai berpengaruh positif dan signifikan terhadaap kinerja SIA. Gustiyan (2014) juga menyatakan hal yang sama. Berbeda dengan hasil penelitian Prabowo et al. (2014) yang menyatakan bahwa kemampuan pemakai tidak berpengaruh signifikan terhadap kinerja SIA.

Berdasarkan Tabel 2, hasil penelitian diketahui bahwa variabel Atitude Toward Change berpengaruh positif terhadap kinerja sistem informasi akuntansi. Hasil analisis menunjukkan bahwa nilai signifikansi uji t untuk variabel Atitude Toward Change sebesar 0,014 yaitu lebih kecil dari taraf nyata 0,05. Hal ini menunjukkan bahwa Atitude Toward Change berpengaruh pada kinerja sistem informasi akuntansi. Koefisien regresi bernilai positif sebesar 0,914. Artinya Atitude Toward Change menunjukkan arah positif pada kinerja sistem informasi akuntansi. Hipotesis pertama $\left(\mathrm{H}_{4}\right)$ pada penelitian ini diterima.

Semakin baik sikap terhadap perubahan sistem yang memiliki kecanggihan teknologi maka akan membantu perusahaan menghasilkan informasi yang cepat dan akurat dalam membuat keputusan yang efektif dan semakin meningkatan efektivitas kinerja sistem informasi akuntansi. Sikap terhadap perubahan organisasi Khatoon \& Farooq (2014) sebuah sikap emosional karyawan untuk menilai dampak baik atau buruk dari suatu perubahan yang terjadi. Mereka juga mempertimbangkan perubahan sebagai bidang yang muncul dari sikap positif yang kuat (keterbukaan, kemauan untuk berubah) terhadap sikap negatif (resisten, pesimis). Berdasarkan pengertian diatas, sikap positif karyawan terhadap perubahan organisasi memiliki peran yang penting dalam tercapainya tujuan-tujuan organisasi.

Berdasarkan Tabel 2, hasil penelitian diketahui bahwa variabel pada penelitian ini menyatakan bahwa variabel Perceived Usefulness dengan Atitude Toward Change $\left(\mathrm{X} . \mathrm{M}_{2}\right)$ tidak berpengaruh positif terhadap kinerja sistem informasi akuntansi. Hasil analisis menunjukkan bahwa nilai signifikansi uji t untuk variabel Perceived Usefulness dengan Atitude Toward Change (X.M $\mathrm{M}_{2}$ ) sebesar 0,377 yaitu lebih kecil dari taraf nyata 0,05 . Hal ini menunjukkan bahwa Perceived Usefulness dengan Atitude Toward Change $\left(\mathrm{X}_{\mathrm{M}} \mathrm{M}_{2}\right)$ tidak berpengaruh pada kinerja sistem informasi akuntansi. Koefisien regresi bernilai sebesar -0,020. Artinya Perceived Usefulness dengan Atitude Toward Change $\left(\mathrm{X}_{\mathrm{M}} \mathrm{M}_{2}\right)$ menunjukkan arah negatif pada kinerja sistem informasi akuntansi. Hipotesis pertama $\left(\mathrm{H}_{5}\right)$ pada penelitian ini ditolak.

\section{SIMPULAN}

Persepsi manfaat (perceived usefulness) berpengaruh positif pada kinerja sistem informasi akuntansi. Model TAM dapat menjelaskan bahwa persepsi pengguna akan menentukan sikapnya dalam kemanfaatan penggunaan sistem informasi. Kemampuan pengguna berpengaruh positif pada kinerja sistem informasi yaitu dapat dilihat dari "Knowledge, Ability, and Skills". Kemampuan Pengguna memeperkuat Pengaruh Perceived Usefulness terhadap kinerja sistem informasi akuntansi. Atitude Toward Change berpengaruh positif terhadap Kinerja Sistem 
Informasi Akutansi. Sementara, Atitude Toward Change tidak dapat memoderasi hubungan Perceived Usefulness terhadap kinerja sistem informasi

Penelitian ini hanya terbatas pada LPD Kecamatan Sukawati, Gianyar, Bali. Sehingga, Peneliti selanjutnya disarankan untuk melakukan penelitian pada jenis perusahaan atau instansi berbeda, sehingga hasil penelitian dapat lebih digeneralisasikan. Hal ini dikarenakan hasil penelitian mungkin saja berbeda jika diterapkan pada jenis perusahaan yang berbeda. Selain itu disarakan juga agar dapat mengembangkan penelitian ini dengan menambah variabel lain yang dapat meningkatkan kinerja sistem informasi akuntansi.

\section{REFERENSI}

Alannita, N. P., \& Suaryana, I. G. N. A. (2014). Pengaruh Kecanggihan Teknologi Informasi, Partisipasi Manajemen, Dan Kemampuan Teknik Pemakai Sistem Informasi Akuntansi Pada Kinerja Individu. E-Jurnal Universitas Udayana, $6(1), 33-45$.

Almilia, L. S., \& Briliantien, I. (2007). Faktor-Faktor Yang Mempengaruhi Kinerja Sistem Informasi Akuntansi Pada Bank Umum Pemerintah Di Wilayah Surabaya Dan Sidoarjo. Jurnal STIE Perbanas Surabaya, 1-7.

Ariyanto, D., Subroto, B., Purnomosidhi, B., \& Rosidi. (2014). Does the Balinese Tri Hita Karana Culture Affect the Adoption and Usage of Information Technology Systems? Information and Knowledge Management, 9(4), 1-16.

Buana, I. B. G. M. M., \& Wirawati, N. G. P. (2018). Pengaruh Kualitas Sistem Informasi , Kualitas Informasi, dan Perceived Usefulness Pada Kepuasan Pengguna Sistem Informasi Akuntansi. E-Jurnal Akuntansi Universitas Udayana, 22(1), 683-713.

Colaizzi, P. R. (1973). Reflection and research in psychology. IA: Kendall/Hunt.

Cummings, T., \& Worley, C. (2008). Organization Development and Change. In Dynamics of Organizational Change and Learning. https://doi.org/10.1002/9780470753408.ch2

Davis, F D. (1985). A technology acceptance model for empirically testing new end-user information systems: Theory and results. Massachusetts Institute of Technology, Sloan School of Management.

Davis, Fred D. (1989). Perceived usefulness, perceived ease of use, and user acceptance of information technology. MIS Quarterly: Management Information Systems, 13(3), 319-339. https://doi.org/10.2307/249008

Davis, Fred D. (1989). Perceived Usefulness, Perceived, And User Acceptance. MIS Quarterly, 13(3), 319-339. https://doi.org/10.2307/249008

Dendawijaya, L. (2009). Manajemen Perbankan. Jakarta: Ghalia Indonesia.

Dewi, N. N. K. A., \& Warmika, I. G. K. (2017). Pengaruh Internet Marketing, Brand Awareness, Dan Wom Communication Terhadap Keputusan Pembelian Produk Spa Bali Alus. E-Jurnal Manajemen Udayana, 6(10), 5580-5606.

Dharmawan, J., \& Ardianto, J. (2017). Pengaruh Kemutakhiran Teknologi, Kemampuan Teknik Personal Sistem Informasi, Program Pelatihan Pengguna Dan Dukungan Manajemen Puncak Terhadap Kinerja Sistem 
Informasi Akuntansi (Studi Empiris Pada Karyawan Perusahaan Retail Consumer Goods Wilayah Tangger. Jurnal ULTIMA Accounting, 9(1), 60-78. https:// doi.org/10.31937/akuntansi.v9i1.588

Fatmawati, I., Cahyono, D., \& Maharani, A. (2019). Pengaruh Partisipasi Pemakai Sistem Informasi, Kemampuan Pemakai Sistem Informasi, Ukuran Organisasi Terhadap Kinerja Sistem Informasi Akuntansi. International Journal of Social Science and Business, 3(1), 11. https://doi.org/10.23887/ijssb.v3i1.17159

Govindarajan, V. (1986). Impact Of Participation In The Budgetary Process On Managerial Attitudes And Performance: Universalistic And Contingency Perspectives. Decision Sciences, 17, 495-518. https://doi.org/10.1111/j.15405915.1986.tb00240.x

Gustiyan, H. (2014). Analisis Faktor - Faktor Yang Mepengaruhi Kinerja Sistem Informasi Akuntansi Pada Bank Perkreditan Rakyat (BPR) Ditanjungpinang. Jurnal Bisnis Dan Akuntansi, 1(1), 1-21.

Hamid, F., Sudibya, I. G. A., \& Rahyuda, A. G. (2017). Pengaruh Kepuasan Kerja dan Komitmen Organisasi Terhadap Sikap Pegawai Mengenai Perubahan di Balai Diklat Industri Kementerian Perindustrian Republik Indonesia. E-Jurnal Ekonomi Dan Bisnis Universitas Udayana, 6(4), 1481-1512.

Jayanti, I. K. M., Yuniarta, G. A., \& Julianto, P. (2017). Pengaruh Kemampuan Teknik Personal, Pendidikan dan Pelatihan Pengguna Serta Dukungan Manajemen Puncak Terhadap Kinerja Sistem Informasi Akuntansi Pada SPPBE di Kabupaten Tabanan. E-Journal S1 Ak Universitas Pendidikan Ganesha, $8(2), 1-12$.

Jogiyanto. (2010). Analisa dan Desain Sistem Informasi. Yogyakarta: Andi.

Julianto, I. P., \& Yasa, I. N. P. (2019). The Analysis of Technology Acceptance Model (TAM) on The Use of Accounting Information System. https:/ / doi.org/10.2991/teams-18.2019.48

Khatoon, S., \& Farooq, A. (2014). Employees'attitude Toward Change And Organizational Performance. Prestige International Journal of Management and Research, 347.

Laudon, K. C., \& Laudon, J. P. (2008). Sistem Informasi Manajemen Terjemahan Chriswan Sungkono dan Machmudin Eka P. Edisi 10.

Murray, D. (1990). The performance effects of participative budgeting: An integration of intervening and moderating. Behavioral Research in Accounting, 104-123.

Pavlou, P. A. (2001). Integrating Trust in Electronic Commerce with the Technology Acceptance Model: Model Development and Validation. Seventh Americas Conference on Information Systems.

Perbarini, A., \& Juliarsa, G. (2012). Analisis Faktor-Faktor Yang Mempengaruhi Kinerja Sistem Informasi Akuntansi Pada LPD Di Kecamatan Denpasar Utara. E-Jurnal Akuntansi, 9(3), 728-746.

Perkasa, A. T. (2016). Pengaruh Persepsi Kebermanfaatan, Persepsi Kemudahan Penggunaan dan Persepsi Kepercayaan Wajib Pajak Terhadap Minat Menggunakan E-filing Sebagai Sarana Pelaporan Pajak (Study Kasus di PT Pelabuhan Indonesia III Cabang Benoa). Jurnal Ilmiah Mahasiswa FEB, 4(2).

Prabowo, G. R., Mahmud, A., \& Murtini, H. (2014). Faktor-Faktor Yang 
Mempengaruhi Kinerja Sistem Informasi Akuntansi (Studi Kasus Pada Lingkungan Pemerintah Kabupaten Temanggung). Accounting Analysis Journal, 3(1), 9-17. https:/ / doi.org/10.15294/aaj.v3i1.3894

Puspitawati, L., \& Anggadini, S. D. (2011). Sistem Informasi Akuntansi. Yogyakarta: Graha Ilmu.

Putri, N. W. I. D., \& Dharmadiaksa, I. B. (2015). Pengaruh Kemampuan Teknik Personal , Program Pelatihan Dan Pendidikan , Insentif , Penerapan Sia. EJurnal Akuntansi Universitas Udayana 12.3, 12(3), 582-592.

Robbins, S. P., \& Judge, T. A. (2008). Perilaku Organisasi Jilid II. Salemba Empat.

Ronaldi, H. (2012). Analisis Faktor-Faktor Yang Mempengaruhi Kinerja Sistem Informasi Akuntansi (Sia). Berkala Ilmiah Mahasiswa Akuntansi, 1(3), 70-76. https://doi.org/10.33024/.v2i1.528

Santoso, B. (2010). Pengaruh Perceived Usefulness, Perceived Ease of Use, dan Perceived Enjoyment Terhadap Penerimaan Teknologi Informasi. Jurnal Akuntansi Dan Bisnis (JAB), 10(2). https:/ / doi.org/10.20961/jab.v10i2.112

Septianingrum, P. A. (2014). Pengaruh Dukungan Top Management, Kemampuan Pengguna, Serta Adanya Pelatihan Dan Pendidikan Pengguna Terhadap Kinerja Sistem Informasi Akuntansi (Studi Kasus Pada BPJS Ketenagakerjaan Semarang dan D.I Yogyakarta). In Implementation Science.

Suardikha, I. M. S. (2013). Pengaruh Budaya Tri Hita Karana Terhadap Penggunaan Sistem Informasi Akuntansi Dimediasi Persepsi Kegunaan Dan Persepsi Kemudahan Penggunaan. Jurnal Akuntansi Dan Keuangan Indonesia, 10(1), 102-128. https:/ / doi.org/10.21002/jaki.2013.06

Suartana, I. W. (2009). Arsitektur Pengelolaan Risiko pada LPD (Lembaga Perkreditan Desa). Udayana University Press.

Sudibyo, S. K., \& Kuswanto, H. (2011). Analisis Faktor-Faktor Yang Mempengaruhi Kinerja Sistem Informasi Akuntansi Pada Pt. Bpr Weleri Makmur Jawa Tengah. Jurnal Ekonomi Manajemen Akuntansi, 18(31).

Susanto, A. (2014). Sistem Informasi Akuntansi 1 Edisi 8. Bandung: Alfabeta.

Tokic, M., Spanja, M., Tokic, I., \& Blazevic, I. (2011). Functional Structure Of Entrepreneurial Accounting Information Systems. Annals of the Faculty of Engineering Hunedoara, 9(2), 165-168.

Widyantari, N. W. L., \& Suardikha, I. M. S. (2016). Pengaruh Pelatihan Dan Pendidikan, Pengalaman Kerja Dan Partisipasi Manajemen Pada Efektivitas Penggunaan Sistem Informasi Akuntansi. E-Jurnal Akuntansi Universitas Udayana, $\quad$ 17(2), 2302-8556. https://ojs.unud.ac.id/index.php/Akuntansi/article/view/23355

$\mathrm{Xu}, \mathrm{H} .$, \& Lu, D. (2003). The Critical Success Factors For Data Quality In Accounting Information System --- Different Industries' Perspective. International Association of Computer Investigative Specialist.

Yogiswara, G. H., \& Suardikha, I. M. S. (2018). Pengaruh Sistem Informasi Akuntansi pada Profitabilitas dengan Ketidakpastian Tugas sebagai Variabel Pemoderasi. E-Jurnal Akuntansi, 25(3), 1634-1661. https://doi.org/10.24843/eja.2018.v25.i03.p01 